\title{
Spark Plasma Sintering of Nano Silicon Carbide Reinforced Alumina Ceramic Composites
}

\author{
Mustafa Guven Gok \\ Hakkari University, Engineering Faculty, Materials Science and Eng. Department, Turkey
}

\begin{abstract}
Although $\mathrm{Al}_{2} \mathrm{O}_{3}$ has been commercially preferred material, it cannot be used in applications subject to variable and sudden loads due to its low fracture toughness. In this study, as the primary purpose, nano-SiC particles were used as reinforcement phase to improve the fracture toughness of the $\mathrm{Al}_{2} \mathrm{O}_{3}$ ceramic. Ultrasonic dispersion was used to ensure good dispersion of the nano reinforcement phase in the matrix. Production was carried out by spark plasma sintering method at temperatures of $1325^{\circ} \mathrm{C}$ for 5 min under $40 \mathrm{MPa}$ pressure and vacuum atmosphere. Densification behavior, density, microstructure, phase analysis, hardness and fracture toughness of the sintered $\mathrm{Al}_{2} \mathrm{O}_{3} /$ nano-SiC composites were investigated. The highest hardness and fracture toughness of $22.83 \mathrm{GPa}$ and $6.09 \mathrm{MPa} \cdot \mathrm{m}^{1 / 2}$ were achieved, respectively.
\end{abstract}

Keywords: Spark Plasma Sintering; $\mathrm{Al}_{2} \mathrm{O}_{3}$; Nano-SiC; Ceramic Composite; Fracture Toughness.

\section{INTRODUCTION}

Alumina $\left(\mathrm{Al}_{2} \mathrm{O}_{3}\right)$, as an engineering ceramic, has high melting temperature $\left(2072{ }^{\circ} \mathrm{C}\right)$, high hardness, low density $(3.9$ $\mathrm{gr} / \mathrm{cm}^{3}$ ) and low thermal conductivity. In addition, its corrosion resistance and biocompatibility are very good. Thanks to these features, it has a high potential to be used in a number of sectors such as aerospace and automotive industries, ballistic armor applications, high temperature refractory materials, cutting and abrasive tools and biomaterials. However, fracture toughness value of $\mathrm{Al}_{2} \mathrm{O}_{3}$, which is resistance to crack propagation, is quite low [1-5]. This negative feature limits the use of $\mathrm{Al}_{2} \mathrm{O}_{3}$. On the other hand, there are many studies to increase the fracture toughness of $\mathrm{Al}_{2} \mathrm{O}_{3}$ based ceramics through microstructure control and reinforcement phase mechanisms $[1,3,4,6-9]$. The reinforcement phase mechanism of $\mathrm{Al}_{2} \mathrm{O}_{3}$ matrix is occurred by secondary phases in the forms of particle and/or fiber. Thus, a composite material is produced. As shown schematically in Figure 1, the main purpose of the reinforcement phase mechanism is to reduce the energy of the crack propagating in the matrix. In the crack deflection mechanism given in Figure 1 (a), as the crack moves through the material, when it intersects with the reinforcement particles, the direction of the crack propagation plane changes and its energy decreases. In the other mechanism called as crack branching (Figure 1 (b)), the crack intersecting with the reinforcement particles splits into two or more cracks and its energy decreases. In the case of crack bridging mechanism shown in Figure 1 (c), the reinforcement phase in the form of fiber acts like a spring trying to close the crack and prevents further spreading the crack.

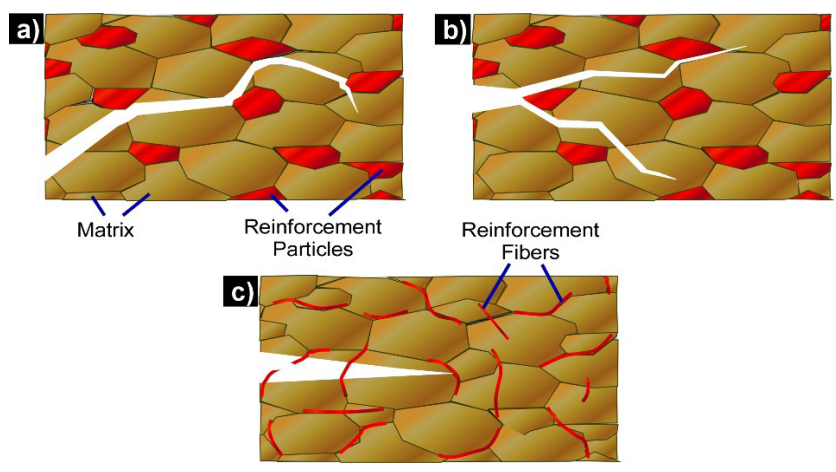

Figure 1. Schematic explanation of the improvement in the fracture toughness through reinforcement phases; crack deflection (a), crack branching (b), crack bridging (c).

When silicon carbide $(\mathrm{SiC})$ is selected as the ceramic reinforcement phase, significant improvements in mechanical properties of the $\mathrm{Al}_{2} \mathrm{O}_{3}$ are possible [10]. At this point, it is reported that the amount, size, morphology and distribution of $\mathrm{SiC}$ phase added into the alumina matrix has a great effect on the mechanical properties of $\mathrm{Al}_{2} \mathrm{O}_{3}$ [11]. Razavi et al. [10] produced the $\mathrm{Al}_{2} \mathrm{O}_{3}$-SiC composite ceramics by using spark plasma sintering (SPS) method at temperatures of $1600{ }^{\circ} \mathrm{C}$ for $10 \mathrm{~min}$ holding time and they measured the hardness and fracture toughness values of the monolithic $\mathrm{Al}_{2} \mathrm{O}_{3}$ as $1387 \mathrm{Hv}$ and $250.4 \mathrm{MPa}$, respectively. Researchers showed that hardness of the composite containing $20 \mathrm{wt}$. \% 
$\mathrm{SiC}$ increased to $2329 \mathrm{Hv}$ and flexural strength of the composite containing $10 \mathrm{wt}$. \% $\mathrm{SiC}$ increased to $293.1 \mathrm{MPa}$. In another study [11], $\mathrm{A}_{2} \mathrm{O}_{3}$-SiC composite containing 17 vol. $\% \mathrm{SiC}$ was produced by SPS method $\left(1550{ }^{\circ} \mathrm{C}\right.$ temperature, $80 \mathrm{MPa}$ pressure and $30 \mathrm{~min}$. holding time) and its hardness value measured as maximum $21.7 \mathrm{GPa}$. Saheb et al. [2] produced the $\mathrm{Al}_{2} \mathrm{O}_{3}-\mathrm{SiC}$-CNT composites using the SPS method at $50 \mathrm{MPa}$ pressure, $1500{ }^{\circ} \mathrm{C}$ sintering temperature and $10 \mathrm{~min}$. holding time. As a result, they showed that while the fracture toughness value of monolithic $\mathrm{Al}_{2} \mathrm{O}_{3}$ was $3.61 \mathrm{MPa}$. $\mathrm{m}^{1 / 2}$, this value increased to $6.98 \mathrm{MPa} \cdot \mathrm{m}^{1 / 2}$ in the composite of $\mathrm{Al}_{2} \mathrm{O}_{3}-10 \mathrm{SiC}-2 \mathrm{CNT}$ (vol. \%). In the study conducted by Alweendo et al. [12] determined the hardness and fracture toughness values of the monolithic $\mathrm{Al}_{2} \mathrm{O}_{3}$ produced by SPS method as $15.8 \mathrm{GPa}$ and $4.2 \mathrm{MPa}^{1 / 2}$, respectively. They also showed that it was possible to increase the hardness and fracture toughness up to $16.1 \mathrm{GPa}$ and $4.7 \mathrm{MPa} \cdot \mathrm{m}^{1 / 2}$, respectively, by adding $10 \% \mathrm{SiC}$ by volume.

On the other hand, although there are other pressure and non-pressure sintering processes in ceramic composite production, SPS is one of the newest and technological methods in the production of engineering ceramics. In this method, heat is produced directly on the powders and the molds thanks to the electric current applied in the form of square wave pulses that can be controlled completely, and therefore, the sintering temperature can be reached in a very short time. During the process, pressure is applied to the powders and the microstructure can be controlled by high heating rate $[10,11]$.

In this study, $\mathrm{Al}_{2} \mathrm{O}_{3} /$ nano-SiC composites containing different ratio of nano-SiC particles (0-30 vol. \%) were produced by using spark plasma sintering process. To achieve good dispersion, the nano-SiC particles were dispersed ultrasonically in the $\mathrm{Al}_{2} \mathrm{O}_{3}$ matrix. The effects of nano-SiC ratio on densification behavior, microstructure, mechanical properties and phase structure of composites were investigated.

\section{MATERIAL AND METHODS}

\subsection{Powder Preparation}

Firstly, commercial $\mathrm{Al}_{2} \mathrm{O}_{3}$ (US Research Nano Materials, USA, an avarage particle size $500 \mathrm{~nm}$, alpha, 99+\%) and (US Research Nano Materials, USA, 45-65 nm, beta, cubic, $99+\%) \mathrm{SiC}$ powders were weighed in the proportions given in Table 1 . Then, the nano $\mathrm{SiC}$ powders were added to the merck quality ethanol in separate beakers. An ultrasonic probe (Heiscer-UP200Ht) was placed in beakers containing ethanol and nano $\mathrm{SiC}$ powders, and dispersion of nano-sized powders in ethanol was provided for 15 minutes. The process was continuously controlled so that the ethanol in the beaker did not overheat, the ethanol was kept cold with the aqueous system placed under the beaker, and the temperature of the system was measured with a thermometer. After the distribution of nano-sized powders, $\mathrm{Al}_{2} \mathrm{O}_{3}$ powders were added to the same beakers in appropriate proportions and ultrasonic dispersion was performed for another 15 minutes. Then, magnetic stirring bars were placed to the beakers and the ethanol evaporated on a magnetic stirrer having heater and vacuum fan. The beakers were placed in a drying-oven at $80^{\circ} \mathrm{C}$ to dry the powders completely.

Table 1. Sample Compositions.

\begin{tabular}{|c|c|c|}
\hline \multirow{2}{*}{ Specimen Name } & \multicolumn{2}{|c|}{ Amount of Powder (vol. \%) } \\
\cline { 2 - 3 } & $\mathrm{Al}_{2} \mathrm{O}_{3}$ & $\mathrm{SiC}$ \\
\hline $100 \mathrm{~A}$ & 100 & - \\
\hline 90A10S & 90 & 10 \\
\hline $80 \mathrm{~A} 20 \mathrm{~S}$ & 80 & 20 \\
\hline 70A30S & 70 & 30 \\
\hline
\end{tabular}

\subsection{Spark Plasma Sintering Process}

Prepared powders were sintered by using spark plasma sintering process. A SPS system (7.40 MK VII, SPS Syntex Inc.) with a capacity of $20000 \mathrm{~A}$ was used. Thanks to this system, composite specimens with $50 \mathrm{~mm}$ diameter and 5 $\mathrm{mm}$ thickness were produced as shown in Figure 2. Graphite molds having $50 \mathrm{~mm}$ inner-diameter and graphite punches were used for composite production. The inner surface of the mold was covered with graphite paper, the lower punch was placed and graphite papers were placed both on the surfaces of upper and lower punches. The powder to be sintered was poured into mold cavity and upper punch placed. Then, the graphite mold was pre-compressed under $10 \mathrm{MPa}$ pressure by using a hand press. In order to minimize heat loss, the graphite molding system was surrounded by a graphite blanket and sintering carried out in a vacuum environment. During SPS process, current was increased manually and shrinkage curves were controlled continuously. $40 \mathrm{MPa}$ pressure was applied to the punches and pulsed direct current (12 ms/on, $2 \mathrm{~ms} / \mathrm{off})$ was passed through the samples and graphite molds during sintering process. The process was completed by holding the specimens 5 minutes at temperature of $1325^{\circ} \mathrm{C}$. Temperature measurements were performed by a pyrometer from the outside of chamber. During sintering, a software was used to control instant parameters such as shrinkage, shrinkage rate, temperature, vacuum value, current, voltage and pressure, and a heating rate of 150 ${ }^{\circ} \mathrm{C} / \mathrm{min}$ was applied.

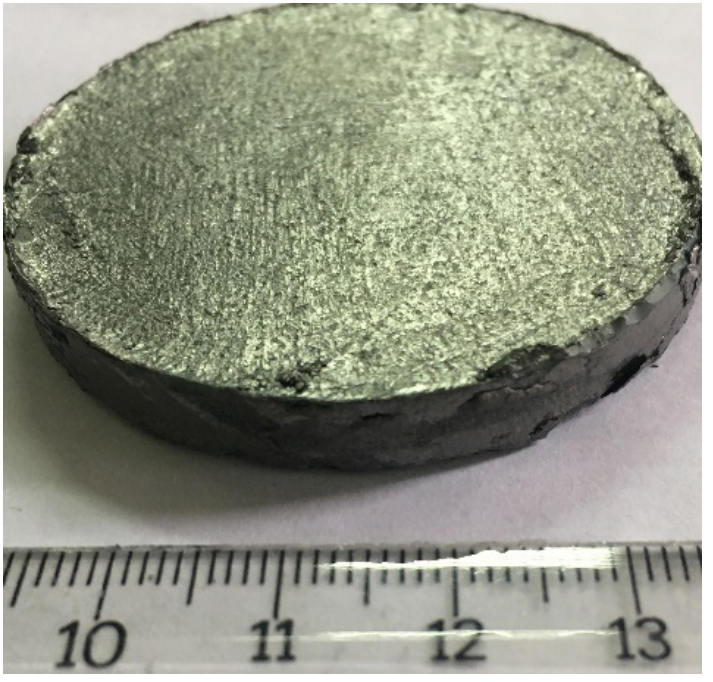

Figure 2. Macro image of the sample produced via SPS process. 


\subsection{Characterization Methods}

The sintering behaviors of the specimens were evaluated by using shrinkage curves obtained from the SPS device. Density of the specimens was determined using Archimedes' principle. Theoretical density values of composites were determined according to the mixture rule and these theoretical values were proportioned to the measured density values. Thus, the relative density values of the composites were calculated (Equation 1).

$$
D_{R}=\frac{D_{B}}{D_{T}} \times 100
$$

In this equation, $D_{R}$ is the relative density $\left(\mathrm{g} / \mathrm{cm}^{3}\right), D_{B}$ is the density of the sintered sample $\left(\mathrm{g} / \mathrm{cm}^{3}\right)$ and $\mathrm{D}_{\mathrm{T}}$ is the theoretical density. Microstructural and elemental analysis of the samples were performed by using Field Emission Scanning Electron Microscope (FESEM, JEOL JSM 7000F) and Energy Dispersion Spectrometer (EDS - Oxford/Inca), respectively. Phase analysis of the samples were carried out with X-ray diffractometer (XRD, Rigaku Miniflex) using $\mathrm{Cu}-\mathrm{K} \alpha$ radiation at a scanning speed of $2^{\circ} / \mathrm{min}$ at $2 \theta: 10-80^{\circ}$. In addition, the parts cut from the samples were molded with bakelite and polished in the automatic polishing machine (Metcon) using various levels of sandpaper and piano discs. In the final stages, surface polishing process was applied with $3 \mu \mathrm{m}$ and $1 \mu \mathrm{m}$ diamond paste. The hardness of the samples was determined in a Vickers microhardness measuring device (Leica VH-MOT) by applying 12 seconds of action time and $9.8 \mathrm{~N}$ load. At least 15 measurements were taken for each sample and both average hardness values and standard deviations were calculated. Fracture toughness measurements
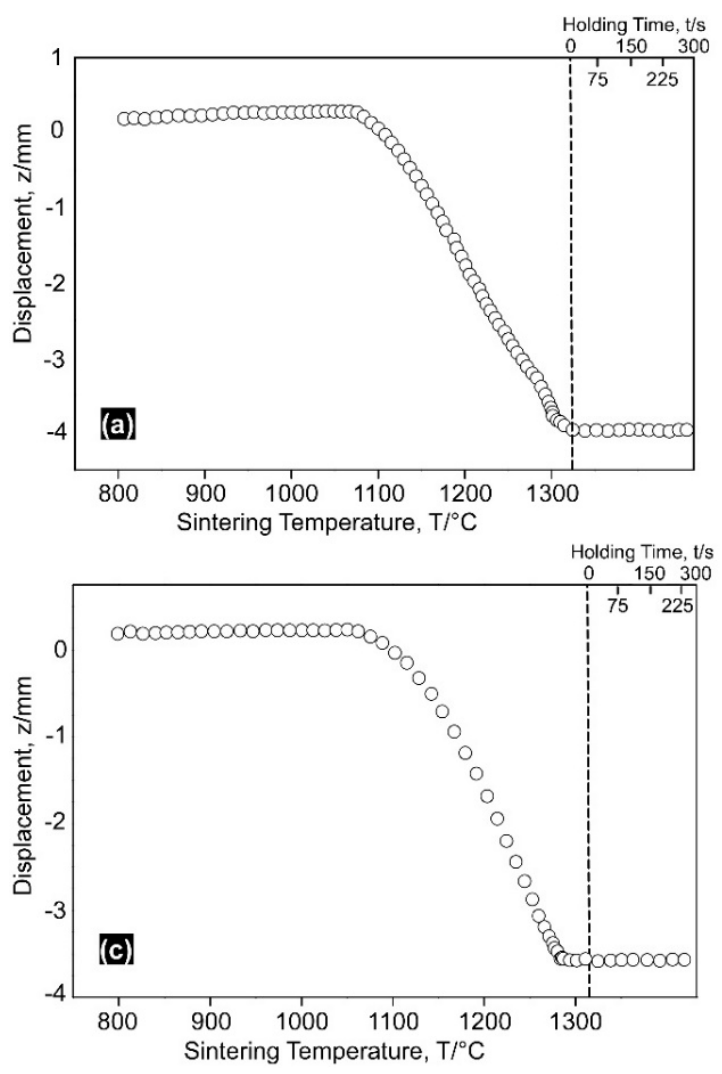

Figure 3. Shrinkage graphs of the samples produced by SPS process, 100A (a), 90A10S (b), 80A20S (c) and 70A30S(d). of the samples were also carried out using the same hardness device, applying 12 seconds of action time and $19.6 \mathrm{~N}$ load. The elasticity modules of the composites were calculated with the rule of mixtures. Fracture toughness values of the samples were calculated by Anstis equation (Equation 2) [13].

$$
K_{I C}=k \times\left(\frac{E}{H}\right)^{1 / 2} \times\left(\frac{P}{c^{3 / 2}}\right)
$$

here; $k$ is the geometry constant $(0.016 \pm 0.004), P$ is the applied load, $E$ is the modulus of elasticity of the composite, $H$ Vickers hardness value and $c$ is half of the average crack length.

\section{RESULTS AND DISCUSSIONS}

\subsection{Densification behavior}

The shrinkage curves for the produced samples were given in Figure $3(\mathrm{a}-\mathrm{d})$. These graphs were plotted as displacement of graphite punches $(\mathrm{mm})$ versus temperature $\left({ }^{\circ} \mathrm{C}\right)$.

During the SPS process, the densification occurring in the powders with the increase of temperature at constant pressure is determined from the displacement amount of the graphite punches due to the shrinkage. After a certain temperature value that is different for each material and composition, the shrinkage is completed and remains constant $[6,8]$. Therefore, in order to obtain a dense structure, the sintering temperature should be equal or higher than the temperature at which shrinkage is completed. In this study, the starting and completion temperatures of the shrinkage for monolithic $\mathrm{Al}_{2} \mathrm{O}_{3}$ and $\mathrm{Al}_{2} \mathrm{O}_{3}$-nano-SiC composite samples were determined (see Table 2).
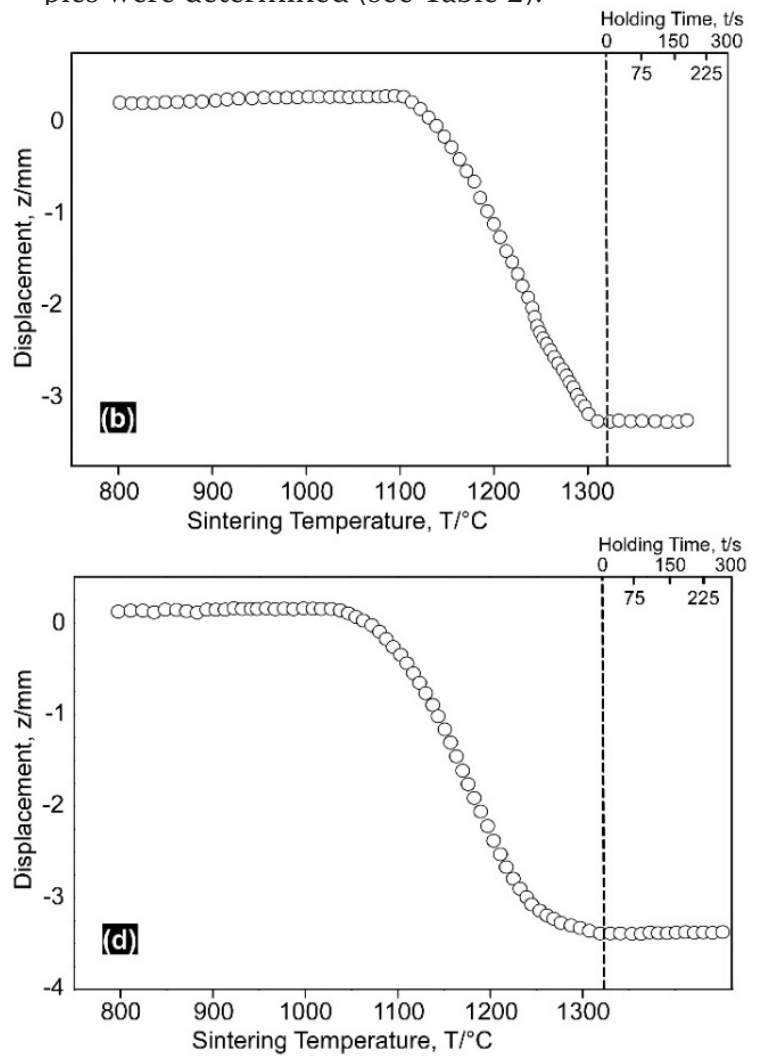


\begin{tabular}{|c|c|c|}
\hline \multirow{2}{*}{ Table 2. Starting and completion temperatures of the shrinkage. } \\
\hline Specimen Name & \multicolumn{2}{|c|}{ Shrinkage Temperatures $\left({ }^{\circ} \mathrm{C}\right)$} \\
\cline { 2 - 3 } & Starting & Completion \\
\hline 100A & 1070 & 1325 \\
\hline 90A10S & 1105 & 1305 \\
\hline 80A20S & 1075 & 1290 \\
\hline 70A30S & 1045 & 1280 \\
\hline
\end{tabular}

As seen in Figure 3 and Table 2, during SPS process performed with a constant heating rate, the starting and completion temperatures of the shrinkage decreased thanks to the nano-SiC added to $\mathrm{Al}_{2} \mathrm{O}_{3}$. The reason for this decrease occurring in the starting and ending temperatures of sintering was thought to be due to the increase in the conductivity of the composite by $\mathrm{SiC}$, whose electrical conductivity is higher than $\mathrm{Al}_{2} \mathrm{O}_{3}$. The mechanism of the increase in electrical conductivity of $\mathrm{Al}_{2} \mathrm{O}_{3}$ by adding $\mathrm{SiC}$ has been explained by Saheb at al [2]. As a result, it is possible to conclude that an improvement took place in the sintering behavior of the $\mathrm{Al}_{2} \mathrm{O}_{3}$ thanks to added nano-SiC particles.

The densities of the specimens produced by the SPS process were determined by Archimedes' Principle. According to the results, it was understood that the relative density values of the specimens varied among $99.7 \%$ and $95.2 \%$ (see Table 3). The monolithic $\mathrm{Al}_{2} \mathrm{O}_{3}$ (99.7\%) had the highest relative density value among all samples. The lowest relative density value (95.2\%) belonged to the specimen of 70A30S sample containing $30 \% \mathrm{SiC}$ by volume. It was determined that relative density values decreased with increasing nano-SiC ra-
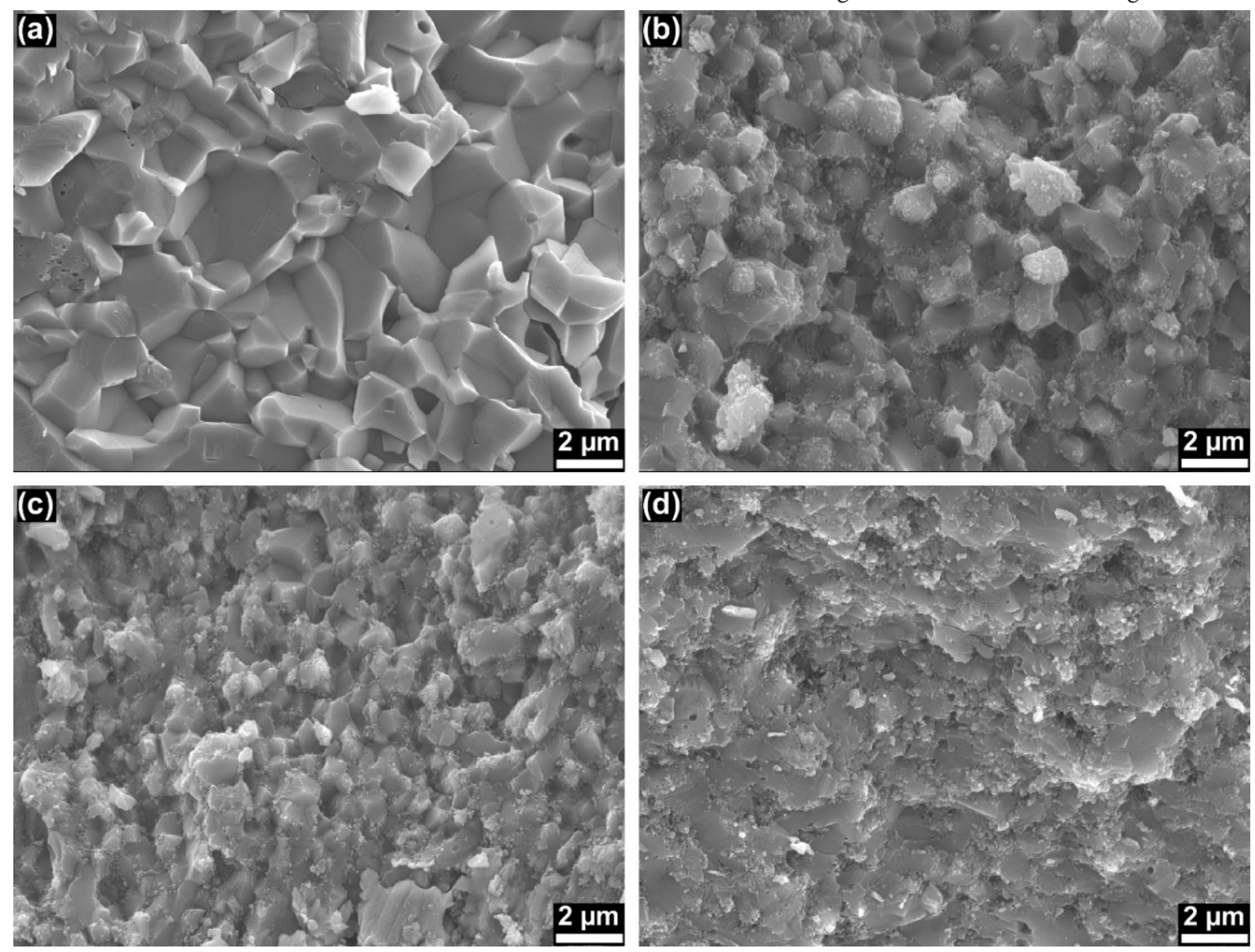

Figure 4. FESEM microstructures of spark plasma sintered specimens; 100A (a), 90A10S (b), 80A20S (c), 70A30S (d). 
with the increasing $\mathrm{SiC}$ ratio. On the other hand, it is clearly seen that the grain size of the $\mathrm{Al}_{2} \mathrm{O}_{3}$ matrix decreased with the addition of nano-SiC to the structure. Nano sized $\mathrm{SiC}$ particles located around $\mathrm{Al}_{2} \mathrm{O}_{3}$ grains and prevented the propagation of the grain boundary. Therefore, the grain size of the $\mathrm{Al}_{2} \mathrm{O}_{3}$ matrix decreased with the nano-SiC addition.

The elemental distributions (by weight) of the EDS spectra taken from the general surface regions of the samples were given in Table 4. In this table, $\mathrm{Al}, \mathrm{Si}, \mathrm{C}$ and $\mathrm{O}$ were chemical symbols of aluminum, silicon, carbon and oxygen, respectively. It is understood that the initial powder compositions (by volume $\rightarrow$ weight) and the values obtained from the EDS results of the produced samples were consistent.

\begin{tabular}{|c|c|c|c|c|}
\multicolumn{5}{|c|}{ Table 4. Results of elemental analysis } \\
\hline \multirow{2}{*}{ Specimen Name } & \multicolumn{4}{|c|}{ Weight \% Element } \\
\cline { 2 - 5 } & Al & Si & C & O \\
\hline 100A & 62,38 & - & - & 37,62 \\
\hline 90A10S & 36,74 & 4,70 & 10,41 & 48,15 \\
\hline 80A20S & 39,60 & 10,60 & 15,84 & 33,96 \\
\hline 70A30S & 22,65 & 12,34 & 27,42 & 37,58 \\
\hline
\end{tabular}

\subsection{Phase Analysis}

In order to understand the phases formed after sintering, XRD analysis were performed and the patterns were given in Figure 5. This process was carried out with an X-ray diffractometer using $\mathrm{Cu}-\mathrm{K} \alpha$ radiation at a scanning speed of $2^{\circ} / \mathrm{min}$ at $2 \theta: 10-80^{\circ}$. As a result, it was understood that the monolithic $\mathrm{Al}_{2} \mathrm{O}_{3}$ sample had the structure of $\alpha-\mathrm{Al}_{2} \mathrm{O}_{3}$ (JCPDS: 71-1683) after SPS process. In case of adding SiC up to $20 \%$, the peaks of the $\mathrm{SiC}$ phase appeared and there was no change in the $\mathrm{Al}_{2} \mathrm{O}_{3}$ structure. However, peaks of the $\mathrm{Al}_{2} \mathrm{Si}_{2} \mathrm{O}_{5}$ phase were revealed in the sample containing $30 \%$ $\mathrm{SiC}$ by volume.

\subsection{Mechanical Properties}

Vickers microhardness and fracture toughness values of $\mathrm{Al}_{2} \mathrm{O}_{3}$-based composites sintered under $40 \mathrm{MPa}$ pressure for $5 \mathrm{~min}$. with the SPS method are given in Table 3. While the hardness value of monolithic $\mathrm{Al}_{2} \mathrm{O}_{3}$ was $18.27 \mathrm{GPa}$, it increased to $21.07 \mathrm{GPa}$ with the addition of $10 \% \mathrm{SiC}$ by volume and 22.34 GPa with the addition of $20 \% \mathrm{SiC}$ by volume. This was due to the nano-SiC particles preventing dislocation movement during plastic deformation caused by hardness measurement. In addition, increasing in hardness could be explained by the reduction of the grain size of $\mathrm{Al}_{2} \mathrm{O}_{3}$ matrix by adding nano-SiC to the structure. The grain boundary areas increased with decrease in grain size and these grain boundary areas prevented the movement of dislocations. However, it was determined that the hardness value did not increase any more if $30 \% \mathrm{SiC}$ by volume was added to the $\mathrm{A}_{2} \mathrm{O}_{3}$ matrix (22.83 $\left.\mathrm{GPa}\right)$.

As a result of fracture toughness measurements, it was understood that a significant improvement occurred in the fracture toughness value with nano-SiC addition to $\mathrm{Al}_{2} \mathrm{O}_{3}$ (Table 3). The fracture toughness value of monolithic $\mathrm{Al}_{2} \mathrm{O}_{3}$, calculated as $2.94 \mathrm{MPa} \cdot \mathrm{m}^{1 / 2}$, increased to 5.81 and 6.09

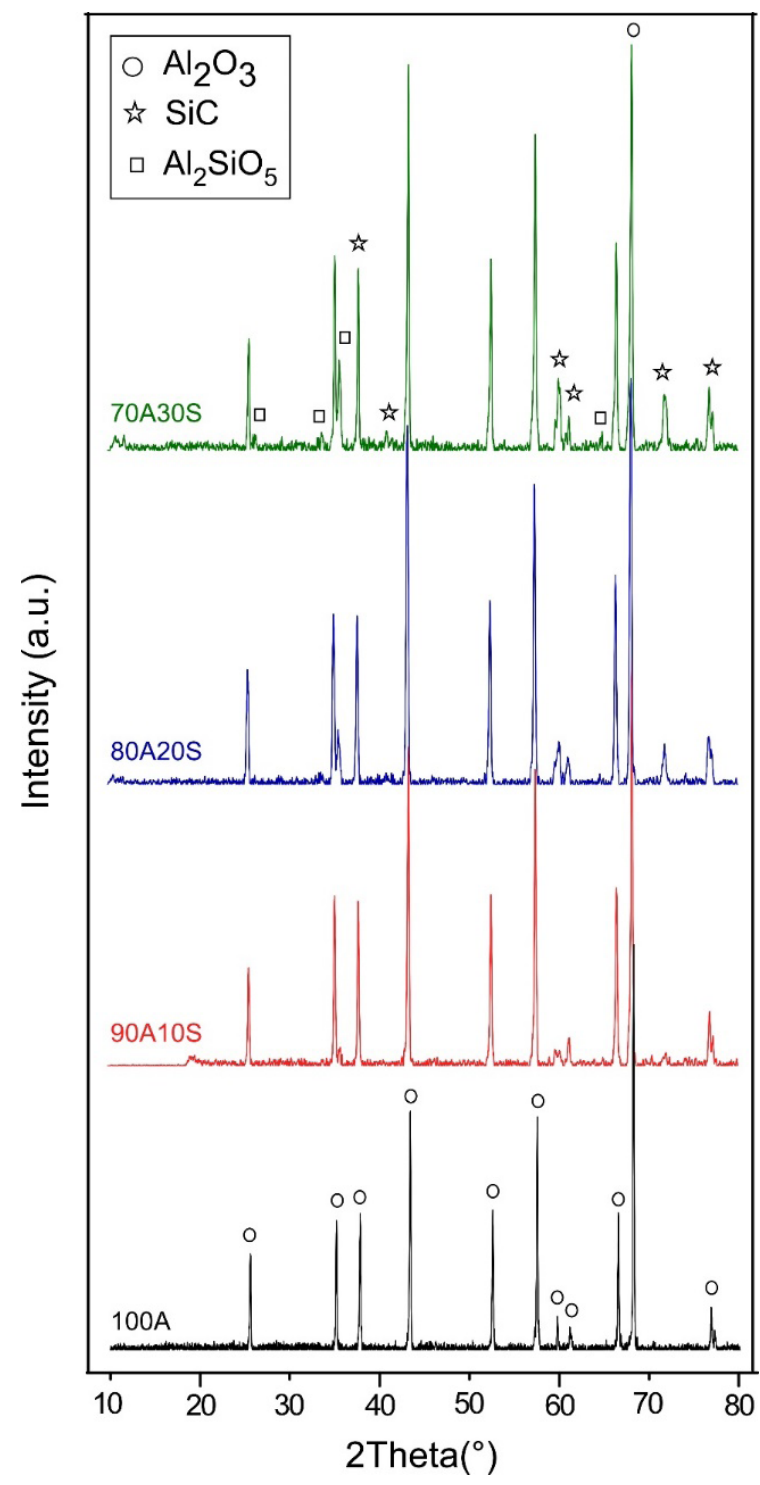

Figure 5. XRD patterns.

$\mathrm{MPa} \cdot \mathrm{m}^{1 / 2}$ with the addition of $10 \%$ and $20 \% \mathrm{SiC}$, respectively. This increase in fracture toughness can be explained by the "Crack Deflection" mechanism caused by nano-sized SiC particles, as Shi et al [14] mentioned. The directions of the cracks propagating in the structure changed when they intersected with the $\mathrm{SiC}$ grains and moved in a zigzag pattern (see Figure 6). In this way, the energy of the cracks was reduced and the fracture toughness values of the $\mathrm{Al}_{2} \mathrm{O}_{3}$-nano $\mathrm{SiC}$ composite were improved.

However, the fracture toughness value of $\mathrm{Al}_{2} \mathrm{O}_{3}$ containing $30 \%$ nano-SiC by volume decreased to $4.37 \mathrm{MPa} \cdot \mathrm{m}^{1 / 2}$. A similar decrease in fracture toughness after a certain $\mathrm{SiC}$ addition (30\% $\mathrm{SiC}$ by weight) was observed in a study in the literature [15]. This situation was explained by three mechanisms: (I) high agglomeration of nano-SiC particles occurring at 30\% $\mathrm{SiC}$ addition (see Figure 7), (II) low fracture toughness of the $\mathrm{Al}_{2} \mathrm{Si}_{2} \mathrm{O}_{5}\left(1-1.8 \mathrm{MPa} \cdot \mathrm{m}^{1 / 2}\right.$ [16]), which formed in the 70A30S sample, (III) excessive residual stresses in the structure as a result of thermal expansion mismatches of $\mathrm{Al}_{2} \mathrm{O}_{3}$ and $\mathrm{SiC}$. As seen in Figure 7, which is the high magnification SEM image of 70A30S, nano-SiC particles agglomerated in the $\mathrm{Al}_{2} \mathrm{O}_{3}$ grain boundary regions when $30 \%$ nano- $\mathrm{SiC}$ by vol- 
ume was added.

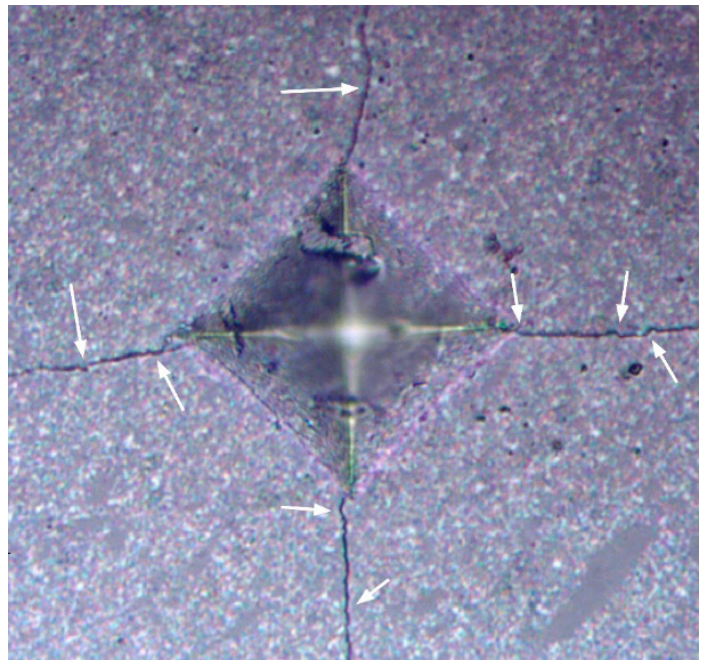

Figure 6. Vickers indentation cracks on the surface of produced $\mathrm{Al}_{2} \mathrm{O}_{3}$-nano $\mathrm{SiC}$ composite.

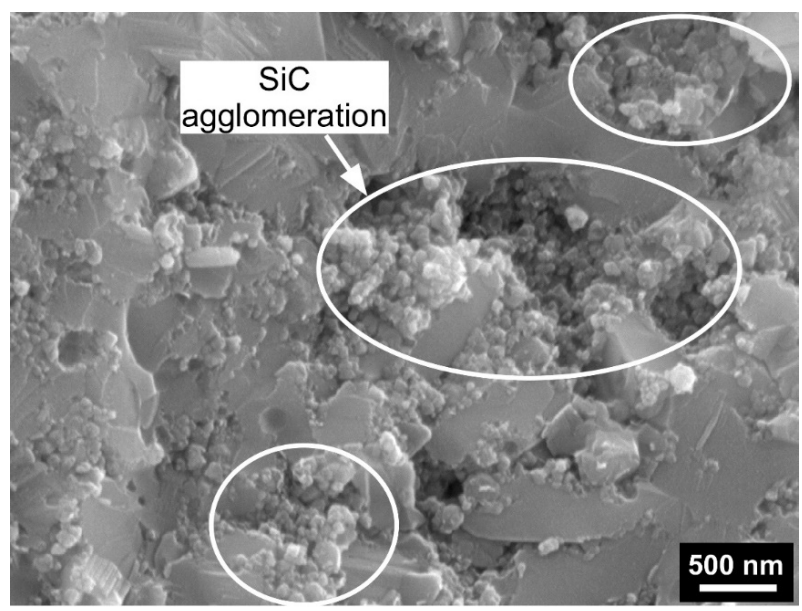

Figure 7. Agglomeration of nano-SiC particles in the grain boundary regions of $\mathrm{Al}_{2} \mathrm{O}_{3}$.

\section{CONCLUSIONS}

As a result of the experimental studies, cylindrical shaped $\mathrm{Al}_{2} \mathrm{O}_{3} /$ nano-SiC specimens with a diameter of $50 \mathrm{~mm}$ were produced by spark plasma sintering process and their sintering behavior, density, microstructure, phase structure, hardness and fracture toughness were analyzed. According to these analysis:

1. The temperatures at which shrinkage started and completed were decreased with the increasing $\mathrm{SiC}$ addition. This situation was explained by the increase in the conductivity of the composite with the increasing $\mathrm{SiC}$ addition.

2. The relative density of monolithic $\mathrm{Al}_{2} \mathrm{O}_{3}$ was $99.7 \%$. However, this value decreased up to $95.2 \%$ with the increasing $\mathrm{SiC}$ addition.

3. The grain size decreased and the fracture mode changed to transgranular fracture from intergranular fracture with the $\mathrm{SiC}$ addition.

4. The hardness increased from 18.27 GPa to 22.83 GPa.

5. While the fracture toughness of the monolithic $\mathrm{Al}_{2} \mathrm{O}_{3}$ was 2.94 $\mathrm{MPa} \cdot \mathrm{m}^{1 / 2}$, a maximum value of $6.09 \mathrm{MPa} \cdot \mathrm{m}^{1 / 2}$ was obtained with the addition of nano-SiC.

6. Addition of $20 \mathrm{vol} \% \mathrm{SiC}$ was the maximum point for mechanical properties, and over this addition amount the fracture toughness value decreased due to the agglomeration of nano- $\mathrm{SiC}$, excessive residual stress and the formation of $\mathrm{Al}_{2} \mathrm{Si}_{2} \mathrm{O}_{5}$ phase.

\section{Acknowledgments}

This work was supported by the Hakkari University Scientific Research Projects Unit (project number: FM2017BAP10). The author thanks to Prof. Dr. Gultekin Goller for his permission to use Biomaterials Research and Characterization Laboratory of Istanbul Technical University.

\section{REFERENCES}

[1] Pravarthana, D., Chateigner, D., Lutterotti, L., Lacotte, M., Marinel, S., Dubos, P.A., et al., (2013). Growth and texture of spark plasma sintered Al2O3 ceramics: A combined analysis of $\mathrm{X}$-rays and electron back scatter diffraction. Journal of Applied Physics. 113(15): 153510. doi: 10.1063/1.4802439.

[2] Saheb, N., Hayat, U., Hassan, S.F., (2019). Recent advances and future prospects in spark plasma sintered alumina hybrid nanocomposites. Nanomaterials. 9(11): 1-43. doi: 10.3390/nano9111607.

[3] Liu, J., Li, Z., Yan, H., Jiang, K., (2014). Spark plasma sintering of alumina composites with graphene platelets and silicon carbide nanoparticles. Advanced Engineering Materials. 16(9): 1111-8. doi: 10.1002/adem.201300536.

[4] Liu, J., Yan, H., Jiang, K., (2013). Mechanical properties of graphene platelet-reinforced alumina ceramic composites. Ceramics International. 39(6): 6215-21. doi: 10.1016/j.ceramint.2013.01.041.

[5] Ahmad, K., Pan, W., (2015). Microstructure-toughening relation in alumina based multiwall carbon nanotube ceramic composites. Journal of the European Ceramic Society. 35(2): 663-71. doi: 10.1016/j.jeurceramsoc.2014.08.044.

[6] Akin, I., (2015). Investigation of the microstructure, mechanical properties and cell viability of zirconia-toughened alumina composites reinforced with carbon nanotubes. Journal of the Ceramic Society of Japan. 123(1437): 405-13. doi: 10.2109/jcersj2.123.405.

[7] Chakravarty, D., Bysakh, S., Muraleedharan, K., Rao, T.N., Sundaresan, R., (2008). Spark plasma sintering of magnesia-doped alumina with high hardness and fracture toughness. Journal of the American Ceramic Society. 91(1): 203-8. doi: 10.1111/j.1551-2916.2007.02094.x.

[8] Ormanci, O., Akin, I., Sahin, F., Yucel, O., Simon, V., Cavalu, S., et al., (2014). Spark plasma sintered Al2O3-YSZ-TiO2 composites: Processing, characterization and in vivo evaluation. Materials Science and Engineering C. 40: 16-23. doi: 10.1016/j.msec.2014.03.041.

[9] Rattanachan, S., Miyashita, Y., Mutoh, Y., (2003). Microstructure and fracture toughness of a spark plasma sintered $\mathrm{Al} 2 \mathrm{O} 3$-based composite with $\mathrm{BaTiO} 3$ particulates. Journal of the European Ceramic Society. 23(8): 1269-76. doi: 10.1016/S0955-2219(02)00294-7.

[10] Razavi, M., Farajipour, A.R., Zakeri, M., Rahimipour, M.R., Firouzbakht, A.R., (2017). Production of Al2O3-SiC nano-composites by spark plasma sintering. Boletin de La Sociedad Espanola de Ceramica y Vidrio. 56(4): 186-94. doi: 10.1016/j.bsecv.2017.01.002.

[11] Álvarez, I., Torrecillas, R., Solis, W., Peretyagin, P., Fernández, A., (2016). Microstructural design of Al2O3-SiC nanocomposites by Spark Plasma Sintering. Ceramics International. 42(15): 17248-53. 
doi: 10.1016/j.ceramint.2016.08.019.

[12] Alweendo, S.T., Johnson, O.T., Shongwe, B.M., Kavishe, F.P., Borode, J.O., (2020). Microstructural and mechanical properties of alumina (Al2O3) matrix composites reinforced with $\mathrm{SiC}$ from rice husk by spark plasma sintering. Materials Research. 23(1): 1-9. doi: 10.1590/1980-5373-MR-2019-0363.

[13] Anstis, G.R., Chantikul, P., Lawn, B.R., Marshall, D.B., (1981). A Critical Evaluation of Indentation Techniques for Measuring Fracture Toughness: I, Direct Crack Measurements. Journal of the American Ceramic Society. 64(9): 533-8. doi: https://doi. org/10.1111/j.1151-2916.1981.tb10320.x.

[14] Shi, X.L., Xu, F.M., Zhang, Z.J., Dong, Y.L., Tan, Y., Wang, L., et al., (2010). Mechanical properties of hot-pressed $\mathrm{Al} 2 \mathrm{O} 3 / \mathrm{SiC}$ composites. Materials Science and Engineering A. 527(18-19): 4646-9. doi: 10.1016/j.msea.2010.03.035.

[15] Torosyan, K.S., Sedegov, A.S., Kuskov, K. V., Abedi, M., Arkhipov, D.I., Kiryukhantsev-Korneev, P. V., et al., (2020). Reactive, nonreactive, and flash spark plasma sintering of Al2O3/SiC composites- A comparative study. Journal of the American Ceramic Society. 103(1): 520-30. doi: 10.1111/jace.16734.

[16] Whitney, D.L., Broz, M., Cook, R.F., (2007). Hardness, toughness, and modulus of some common metamorphic minerals. American Mineralogist. 92(2-3): 281-8. doi: 10.2138/am.2007.2212. 